\title{
Zinc flux in Palaemon elegans (Crustacea: Decapoda): moulting, individual variation and tissue distribution
}

\author{
S. L. White and P. S. Rainbow \\ School of Biological Sciences, Queen Mary College, Mile End Road, London E1 4NS, England
}

\begin{abstract}
Zinc flux has been followed through individual shrimp Palaemon elegans using Zn-65 as a tracer. Rates of uptake and loss of labelled zinc varied widely between individuals but could not be attributed to differences in size (dry wt), sex, nor stage in the moult cycle, indicating genetic variation. Rapid zinc flux into the shrimp occurs immediately after moulting and subsequently flux rates are enhanced for several days. The first moult in non-labelled media results in losses of up to $20 \%$ of the previously accumulated labelled zinc burden. Subsequent moults cause insignificant losses of labelled zinc. Moulting under high external zinc levels may cause a small increase $(\simeq 10 \%)$ in the total body zinc concentration, the increase being restricted to the cuticle. Zinc is unevenly distributed between individual tissues of $P$. elegans, the highest concentrations being in the eye $\left(215 \mu \mathrm{g} \mathrm{Zn} \mathrm{g}^{-1}\right.$ dry wt), hepatopancreas (178) and gill (136), the lowest in the muscle (49.6). Individual tissues show different rates of zinc flux, $2.41 \mu \mathrm{g} \mathrm{Zn} \mathrm{g} \mathrm{Zn}^{-1} \mathrm{~d}^{-1}$ in the hepatopancreas to $0.13 \mu \mathrm{g} \mathrm{Zn} \mathrm{g}^{-1} \mathrm{~d}^{-1}$ in the muscle, and also vary in the size of fast and slow exchanging pools of zinc. Zinc in the cuticle is absorbed into internal tissues prior to moulting. Cast moults take up zinc from the surrounding medium.
\end{abstract}

\section{INTRODUCTION}

A number of studies have examined the flux of zinc in a variety of marine crustaceans using $\mathrm{Zn}-65$ as a tracer for zinc (e.g. Euphausia pacifica: Fowler et al., 1971; Gammarus locusta and Lysmata seticaudata: Fowler et al., 1975; Pachygrapsus marmoratus: Heyraud and Fowler, 1973). The uptake of $\mathrm{Zn}-65$ in $G$. locusta increases towards an asymptote suggesting that an equilibrium is reached between $\mathrm{Zn}-65$ uptake and loss (Fowler et al., 1975). Where the elimination of previously accumulated Zn-65 has been followed such equilibria are implicitly assumed and Zn-65 loss described in terms of compartmental models where $\mathrm{Zn}-65$ is lost at different rates from at least 2 pools (Fowler et al., 1971 and 1975; Heyraud and Fowler, 1973; Small and Fowler, 1973). These studies however do not provide data on total zinc concentrations and therefore it is difficult to interpret what the apparent equilibria and compartments represent. In contrast, Renfro et al. (1975) showed that after $96 \mathrm{~d}$ exposure to Zn-65 the crab Carcinus maenas and the benthic shrimp Lysmata seticaudata had accumulated $\mathrm{Zn}-65$ to an apparent equilibrium level but had concentration factors (c.f's) for $\mathrm{Zn}-65$ that were one quarter and one fifth respectively of the c.f's for total zinc. This indicated that there were pools of zinc in these animals that exchange only slowly with zinc taken up from solution.

The shrimp Palaemon elegans regulates body zinc concentrations over a wide range of external zinc concentrations (White and Rainbow, 1982) and is thus typical of decapod crustaceans (Bryan, 1964, 1968, 1976; Ray et al., 1980). White and Rainbow (1984) considered the regulation of zinc in P. elegans in terms of the metal flux through the whole animal. By following the uptake of labelled zinc and analysing for both labelled and total zinc, it was shown that body zinc consisted of at least 2 pools with different rates of exchange with external zinc. The size of the fast pool (up to $35 \%$ body zinc) and the rate of zinc flux (up to $\mathbf{1 4 . 4} \%$ of the total body zinc $\mathrm{d}^{-1}$ ) were found to vary with both the external zinc concentration and temperature, and showed marked variation between individual shrimp. The present study further examines this individual variability of zinc flux rates and investigates 
effects of moulting upon zinc uptake and loss. In addition zinc flux through individual shrimp tissues is studied and considered in the light of the data on whole shrimp.

\section{MATERIAL AND METHODS}

General points on experimental exposures and details of whole body counting of shrimp, sample preparation and analysis for zinc and zinc- 65 have been given in White and Rainbow (1984).

\section{Experimental details}

Influence of moulting on zinc flux. Groups of 5 shrimp were exposed to 25,50 or $100 \mu \mathrm{g}^{-1} \mathrm{zinc}$, with $\mathrm{Zn}-65$ as a tracer $\left(0.1 \mu \mathrm{Ci} \mathrm{g}^{-1}\right.$ total zinc), for $5 \mathrm{~d}$ in $8 \mathrm{l}$ of the synthetic seawater, Tropic Marin New (TMN), in acid-washed perspex tanks. Labelled zinc uptake was monitored by counting live individual shrimp after 24 , $48,72,96$ and $120 \mathrm{~h}$. Shrimp were then dried, weighed, acid digested and analysed for Zn-65 and total zinc. Throughout the experiment animals were held separately in compartmented perspex boxes, and were fed on lamb's heart once after the $72 \mathrm{~h}$ count. Experimental temperature was $15^{\circ} \mathrm{C} \pm 1 \mathrm{C}^{\circ}$.

Accumulation and loss of labelled zinc by individual shrimp. Twelve individually-held shrimp were exposed to $50 \mu \mathrm{g} \mathrm{l}^{-1}$ zinc, with $\mathrm{Zn}-65\left(0.1 \mu \mathrm{Ci} \mathrm{g}{ }^{-1}\right.$ total zinc), for $10 \mathrm{~d}$ in $15 \mathrm{l}$ of TMN. On Day 10 shrimp were transferred to a clean compartmented box and tank, and further exposed to $50 \mu \mathrm{g} \mathrm{l}^{-1} \mathrm{zinc}_{\text {, with no added }}$ tracer, for a further $35 \mathrm{~d}$. Accumulation and loss of labelled zinc were monitored by periodically counting whole individuals. Additional counts were made for shrimp which were found to have moulted. The experimental medium was changed on Days 10, 13, 17, 20, 25, 30, 35 and 40. Experimental temperature was $15^{\circ} \mathrm{C} \pm 1 \mathrm{C}^{\circ}$.

Zinc flux through individual tissues. Forty Palaemon elegans were exposed to $100 \mu \mathrm{g}^{-1}$ zinc with $2.5 \mu \mathrm{Ci}$ $1^{-1}$ Zn-65 in 101 of TMN for $20 \mathrm{~d}$. On Day 20, shrimp were transferred to clean perspex boxes and put into 201 TMN containing $100 \mu \mathrm{g} \mathrm{l}^{-1}$ zinc with no added tracer for a further $29 \mathrm{~d}$. Except during feeding, shrimp were held separately in compartmented perspex boxes. The experimental medium was changed on Days $10,20,22,24,27,31,37$ and 42 . On Days $0,2,5$, $10,15,20,22,26,31,40$ and 49,4 individuals were removed and dissected into cuticle, abdominal muscle, hepatopancreas, gills, eyes (+ eye stalks) and other soft tissue, 'the rest'. Tissues from individuals were dried and acid digested and the concentration of total zinc and zinc-65 determined.
Shrimp were fed on lamb's heart for $15 \mathrm{~min}$ every second day, but were not maintained individually so the uptake and loss of zinc in relation to moulting could not be determined directly. The experimental temperature was $10^{\circ} \mathrm{C} \pm 1 \mathrm{C}^{\circ}$.

Fitting data to asymptotic and exponential curves was carried out as described in White and Rainbow (1984).

Terminology. To avoid any ambiguity a number of terms used throughout this study will be defined as follows: Labelled zinc - zinc taken up during those stages of experiments where zinc- 65 was added to TMN as a tracer for zinc. Accumulation - the net increase in concentration of zinc, normally labelled zinc. Uptake - the input of zinc into the shrimp. Depuration - the loss, by any means, of labelled zinc.

\section{RESULTS}

\section{Experiment I: influence of moulting on zinc flux}

\section{Zn-65 activity in experimental media}

Samples of TMN taken from experimental tanks containing nominal concentrations of 25,50 or $100 \mu \mathrm{g}$ $\mathrm{Zn} 1^{-1}$ were found to have $\mathrm{Zn}-65$ concentrations within $6 \%$ of the expected values, which will therefore be used in discussing the results.

\section{Total zinc concentrations in shrimp}

Fig. 1 shows the mean total zinc concentrations in

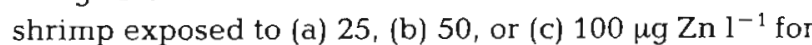
$5 \mathrm{~d}$. Analysis of variance showed a marginally signifi-

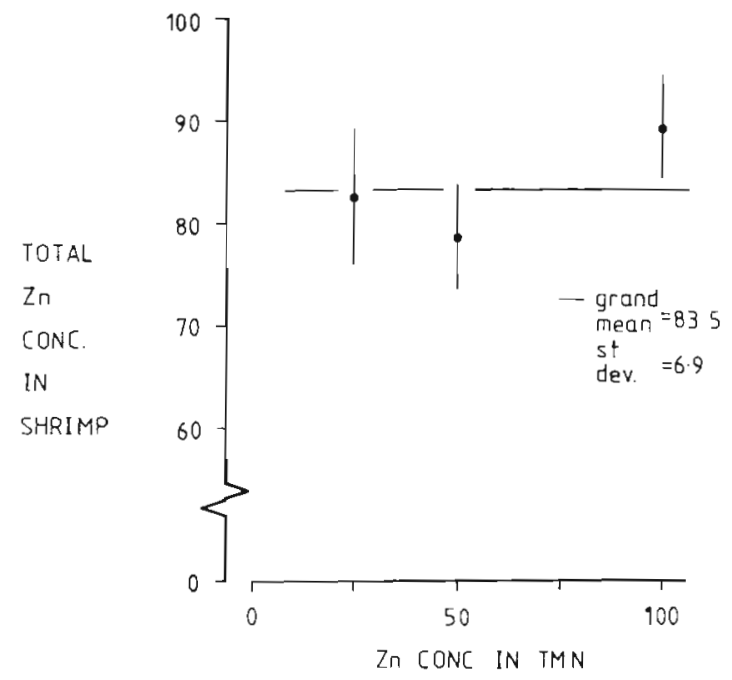

Fig. 1. Palaemon elegans. Mean total zinc concentration ( $\mu \mathrm{g}$ $\mathrm{g}^{-1}$ dry $\mathrm{wt}, \pm 1 \mathrm{SD} ; \mathrm{n}=5$ ) in individual shrimp exposed to 25,50 or $100 \mu \mathrm{g}^{-1}$ of labelled zinc, for $5 \mathrm{~d}$ in TMN 

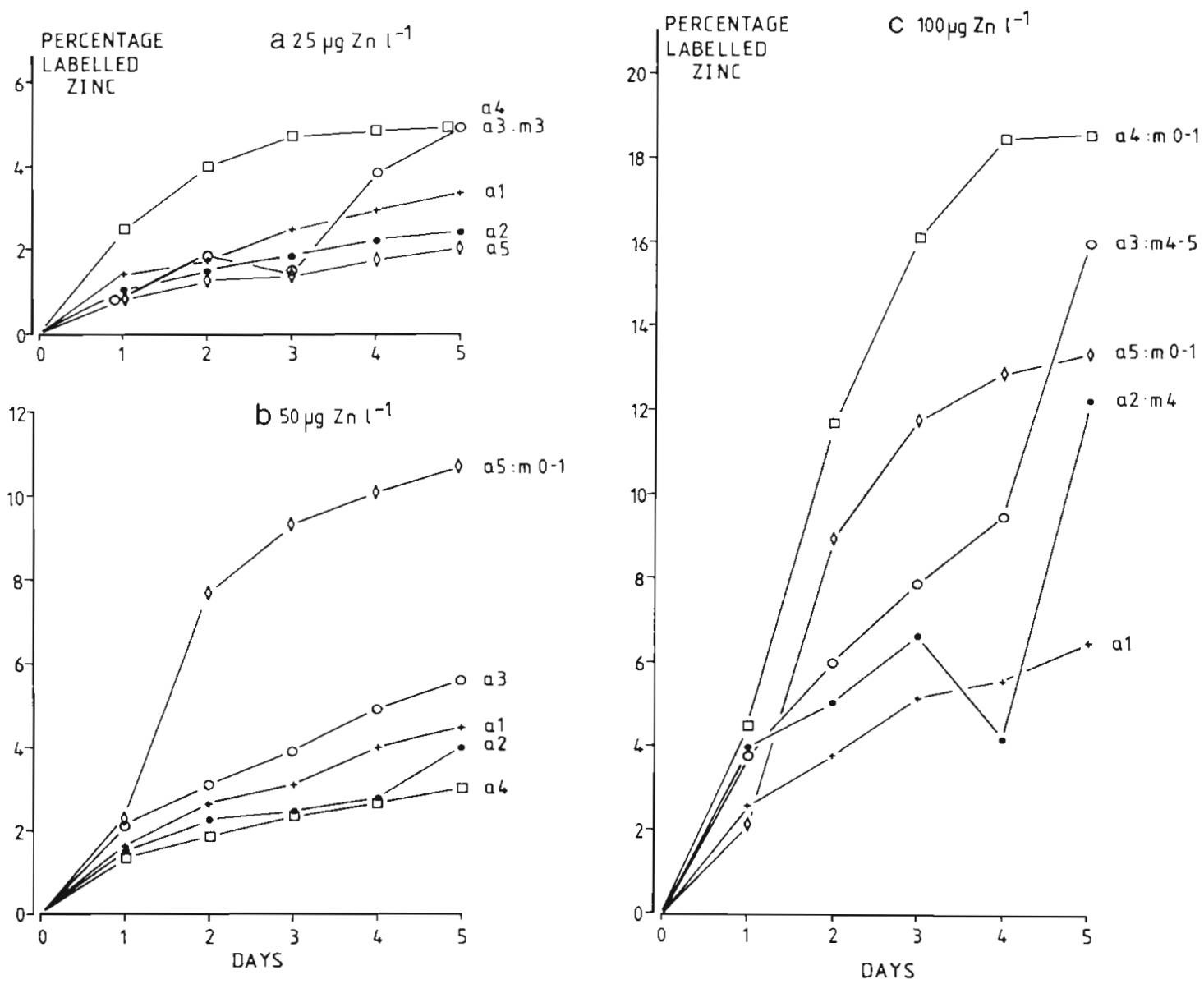

Fig. 2. Palaemon elegans. Uptake of labelled zinc (as percentage of total body zinc) by individual shrimp exposed to (a) $25 \mu \mathrm{g} \mathrm{l}^{-1}$, (b) $50 \mu \mathrm{g} \mathrm{l}^{-1}$, (c) $100 \mu \mathrm{g} \mathrm{l}^{-1}$ labelled zinc for up to $5 \mathrm{~d}$; Expt. I. a: animal number, referred to in text; m: shrimp moulted during experiment, day is given (or interval between days) when moulting occurred

cant difference $(p=0.04)$ in the 3 mean zinc concentrations. Regression analysis however revealed no significant regression ( $p=0.50$ ) between zinc concentration in the shrimp and the zinc concentration in TMN. As other more extensive analyses (White and Rainbow, 1982 and 1984) have shown that Palaemon elegans regulates zinc at the concentrations used here, the observed differences in means in this case are probably a result of individual variability and small sample size.

\section{Uptake of labelled zinc}

Fig. 2 shows labelled zinc uptake by individual shrimp, expressed as a percentage of the total zinc concentration, at (a) 25, (b) 50 and (c) $100 \mu \mathrm{g} \mathrm{Zn} \mathrm{Z}^{-1}$. The pattern of accumulation of labelled zinc is clearly modified by moulting but where moulting has not occurred it appears that the amount of labelled zinc approaches an asymptote, less than $100 \%$ labelled zinc.
Effect of moulting on the uptake and loss of labelled zinc

Fig. 2 illustrates that, at a given concentration, shrimp that moulted during the experiment took up greater amounts of labelled zinc than those that did not moult. There is an immediate initial rapid increase in the percentage of labelled zinc in moulted shrimp (in most cases) which is followed by a period of uptake at a rate lower than the initial increase but still greater than that observed before the moult.

On 2 occasions shrimp moulted less than $5 \mathrm{~min}$ before counting. The 2 individuals (indiv. 3 , in $25 \mu \mathrm{g}$ $\mathrm{Zn} \mathrm{l}^{-1}$, and indiv. 2 in $100 \mu \mathrm{g} \mathrm{l}^{-1} \mathrm{Zn}$ ) showed significant immediate losses of labelled zinc. As the accumulation of labelled zinc would have been continuous up to moulting, the data have been calculated as the percentage of the predicted labelled zinc content, and equalled approximately $45 \%$ for both shrimp. Analysis of the newly shed moults, however, showed that both had labelled zinc contents equivalent to approxi- 
Table 1. Palaemon elegans. Concentrations of labelled and total zinc in moults ( $\mu \mathrm{g} \mathrm{g}^{-1} \mathrm{dry}$ wt) recovered during Experiment II, and a comparison of labelled zinc content of shed moults with the estimated labelled zine content of shrimp prior to moulting

\begin{tabular}{|c|c|c|c|c|c|c|}
\hline $\begin{array}{c}\text { Zinc conc. } \\
\text { in TMN }\end{array}$ & $\begin{array}{l}\text { Shrimp } \\
\text { number }\end{array}$ & $\begin{array}{l}\text { Day } \\
\text { exuvia } \\
\text { shed }\end{array}$ & $\begin{array}{l}\text { Labelled } \\
\text { zinc conc. } \\
\text { of moult }\end{array}$ & $\begin{array}{c}\text { Total } \\
\text { zinc conc. } \\
\text { of moult }\end{array}$ & $\begin{array}{l}\text { Labelled zinc } \\
\text { content } \\
\text { of moult }\end{array}$ & $\begin{array}{l}\text { Estimated labelled } \\
\text { zinc content of } \\
\text { shrimp prior to } \\
\text { moulting }\end{array}$ \\
\hline & & & $\mu g g^{-1}$ & $\mu \mathrm{g} \mathrm{g}^{-1}$ & $\mu \mathrm{g}$ & $\mu \mathrm{g}$ \\
\hline 25 & 3 & $3^{\circ}$ & 5.0 & 10.8 & 0.13 & 0.18 \\
\hline 50 & 5 & 1 & 12.8 & 29.4 & 0.74 & 0.25 \\
\hline 100 & 4 & 1 & 15.0 & 25.9 & 0.62 & 0.23 \\
\hline 100 & 5 & 1 & 13.8 & 24.2 & 0.82 & 0.31 \\
\hline 100 & 2 & $4^{\circ}$ & 14.1 & 27.3 & 0.56 & 0.86 \\
\hline 100 & 3 & 4 & 26.9 & 36.7 & 0.74 & 0.85 \\
\hline
\end{tabular}

mately $70 \%$ of the amount predicted in the shrimp prior to moulting. The difference in the 2 amounts is probably due to the adsorption of zinc onto the newly shed moult which apparently occurs very rapidly.

This observation suggested a more detailed analysis of data related to moults. Table 1 therefore gives concentrations of both labelled and total zinc in all mounts shed during Experiment I. The amount of labelled zinc in the moult approaches or is greater than the estimated (by extrapolation) amount in whole shrimp. Since labelled zinc is taken up into tissues other than the cuticle (see Experiment III) and shrimp do not lose all their labelled zinc on moulting (Fig. 2), the inference is again that labelled zinc has been taken up by the cast moult probably onto newly exposed inner surfaces. Uptake of labelled zinc by the moult is further supported on Day 4 in the $100 \mu \mathrm{g} \mathrm{Zn}^{-1}$ media. The moult shed less than 5 min before counting had a smaller labelled zinc content than the moult shed an intermediate period before counting (Table 1). This difference cannot be explained by different rates of uptake of labelled zinc by the two shrimp (Fig. 2c).

\section{Experiment II: accumulation and loss of labelled zinc by individual shrimp}

\section{Zinc concentrations in TMN}

During the first $10 \mathrm{~d}$ of Experiment II, labelled zinc concentrations varied by less than $10 \%$ from the declared concentration of $50 \mu \mathrm{gl}^{-1}$. It was assumed that during the non-labelled phase of the experiment the total zinc concentration varied to a similar limited degree. Zinc-65 could not be detected in water samples taken after Day 10 and recycling of labelled zinc is therefore considered negligible.

\section{Mortalities during Experiment II}

Only 2 of the 12 shrimp survived the $45 \mathrm{~d}$ experiment. This low survival rate might be explained by the repeated counting of shrimp rather than toxic effects of the zinc, for in another comparable zinc exposure (49 d, see Experiment III) no mortalities were recorded despite the higher zinc concentration $\left(100 \mu \mathrm{g} \mathrm{Zn}^{-1}\right)$. Counting involved the removal of the shrimp from the experimental TMN for about $90 \mathrm{~s}$, and would probably have stressed the shrimp although this procedure does not affect the rate of accumulation of labelled zinc (White and Rainbow, 1984).

\section{Accumulation and loss of labelled zinc}

Fig. 3 shows the amount of labelled zinc in individual shrimp expressed as a percentage of total body zinc content. Owing to the large number of moults in the first $10 \mathrm{~d}$ of the experiment it is not possible to determine if there is any tendency for the amount of labelled zinc to asymptote, as indicated in Experiment I and shown by White and Rainbow (1984). Again the amount of labelled zinc taken up by the shrimp is increased for sometime after moulting.

\section{Loss of labelled zinc}

Fig. 4 shows loss of labelled zinc by individual shrimp as a percentage of the total zinc content on Day 10. Labelled zinc loss in 7 out of the 10 shrimp that survived beyond Day 10 could be adequately described by an exponential curve.

The biological half life $\left(\mathrm{t}_{\mathrm{b} / 2}\right)$ of the labelled zinc in individual shrimp ranged from 7.5 to $19.4 \mathrm{~d}$, but the variation is not related to either the amount of labelled 


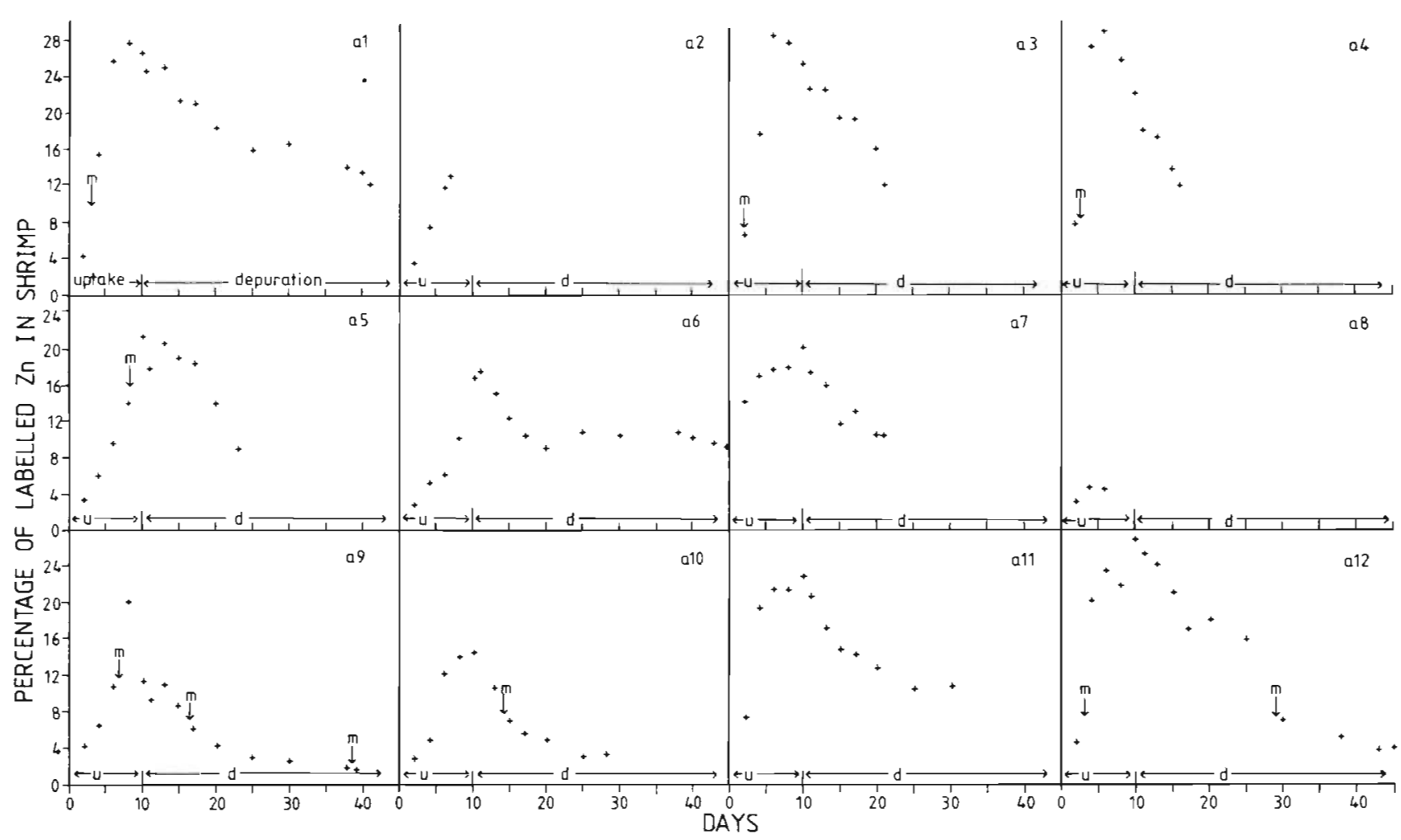

Fig. 3. Palaemon elegans. Uptake and loss of labelled zinc (as percentage of total body zinc) by individual shrimp exposed to $50 \mu \mathrm{g} \mathrm{l}^{-1}$ of labelled zinc for $10 \mathrm{~d}$ (uptake $=\mathrm{u}$ ) and subsequently transferred to $50 \mu \mathrm{g} \mathrm{l}^{-1}$ of unlabelled zinc and exposed for a further $35 \mathrm{~d}$ (depuration $=\mathrm{d}$ ); Expt. II. $\mathrm{m}$ : shrimp moulted; a: individual number referred to in text. Last datum point for each shrimp is at end of experiment (Day 45) or count after shrimp died

zinc accumulated nor to the occurrence of moulting during the first $10 \mathrm{~d}$ of the experiment. In the 3 shrimp that moulted during the depuration phase of the experiment the rate of labelled zinc loss was not significantly different before and after moulting $(p>.05$ in all 3 cases).

For 3 shrimp (1,6 and 11; Fig. 4) labelled zinc loss does not appear linear in a semilogarithmic plot suggesting that it is not a single exponential function but involves a number of components. Although it is possible to subject these data to curve stripping analysis, the variability of the data and the comparatively few data points would make the errors large and any estimates of the size of separate components of little value.

The amount of labelled zinc lost on moulting appears to be related to the total accumulated up to Day 10 rather than the amount of labelled zinc present prior to moulting. Expressed as the percentage of the Day 10 content, the loss of labelled zinc on moulting in Shrimp 9 (first moult only), 10 and 12 were 16.5, 17 and $20 \%$, respectively, whereas in terms of the percentage of the total prior to moulting, losses of labelled zinc on moulting were 37,27 and $45 \%$, respectively, the percentage apparently increasing with time in non-labelled medium before moulting. This suggests that the loss of labelled zinc on moulting is largely indepen- dent of other routes of zinc loss. The amount of labelled zinc lost due to the second moult during the depuration phase, by Individual 9, was no greater than predicted from the plotted regression line (Fig. 4).

Weighing of shrimp every $5 \mathrm{~d}$ revealed a mean wet weight loss of $2 \%$, the largest weight decrease being $6 \%$ the largest increase $2 \%$. These weight changes were considered to have a negligible effect on the pattern of uptake and loss of labelled zinc.

\section{Effect of moulting on total zinc concentrations in shrimp}

Table 2 gives concentrations of zinc in whole shrimp which died during or were sacrificed at the end of Experiment II, arranged according to the number of times that individual shrimp had moulted. Although the mean zinc concentration of shrimp that moulted once during the experiment is greater than the mean zinc concentration of non-moulted shrimp, the difference is not significant ( $p=0.3$ ), nor is there a significant difference between non-moulted shrimp and those that moulted 2 or 3 times $(p \simeq 0.4$ and 0.2 , respectively). There is also no significant relation between body zinc concentration and the number of times that 


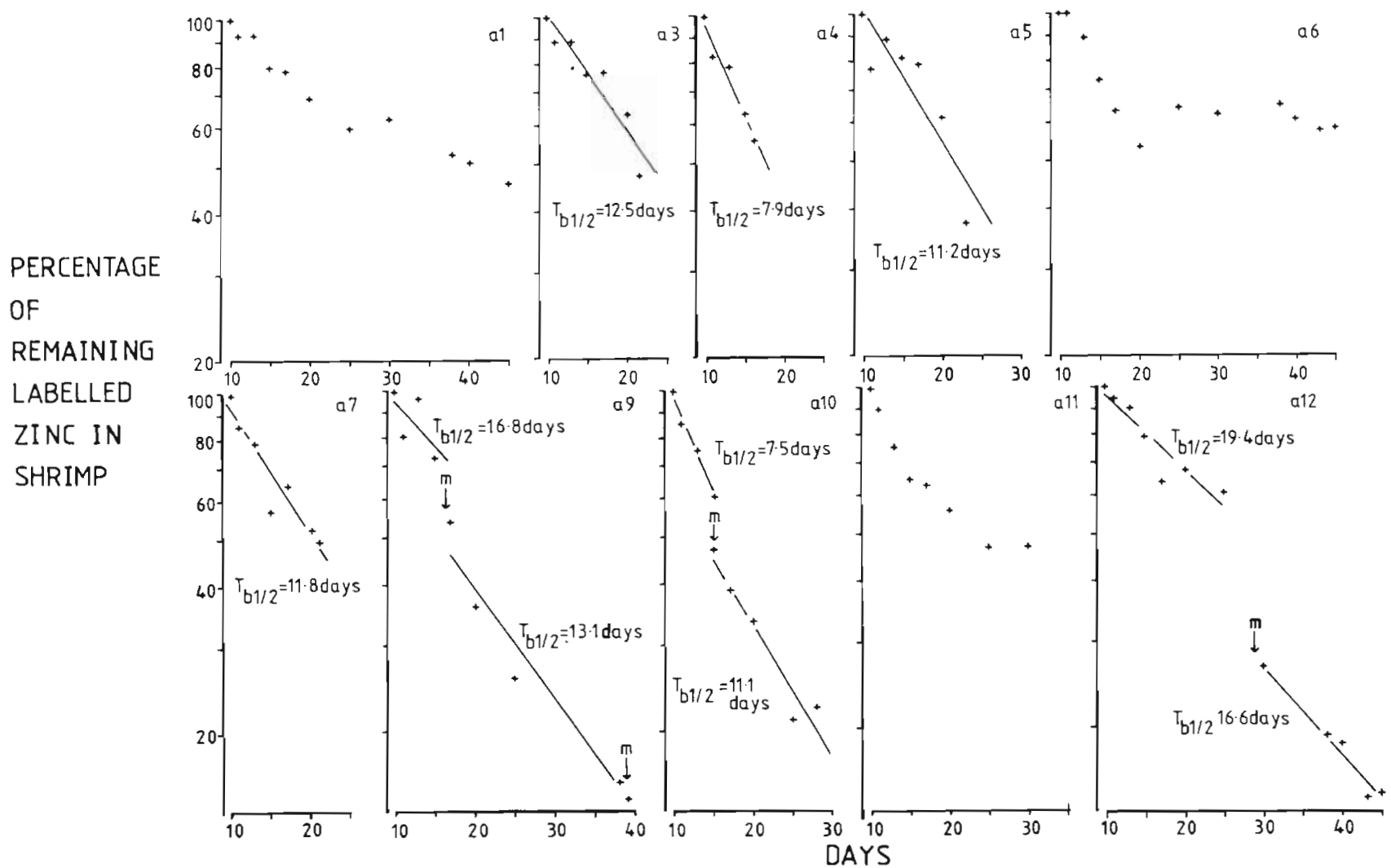

Fig. 4. Palaemon elegans. Loss of labelled zinc by individual shrimp as percentage of calculated labelled zinc content $\left(\mu \mathrm{g} \mathrm{g}^{-1} \mathrm{dry}\right.$ weight) on Day 10; Expt. II. Regression lines fitted by least squares and shown when significant at the p $<0.05$ probability level. $\mathrm{T}_{\mathrm{b} / 2}$ biological half-life of labelled zinc. Other details as for Fig. 3

shrimps moulted $(\mathrm{p} \simeq 0.4$ and $\mathrm{p} \simeq 0.9$ for regression with and without non-moulters, respectively). Analysis of these data therefore indicates that under the conditions used in the Experiment II, there is no significant increase in body zinc concentration with successive moults.

Table 2. Palaemon elegans. Concentrations of zinc in shrimp that died during, or were sacrificed at the end of, Experiment II ( $\mu \mathrm{g} \mathrm{Zn} \mathrm{g}^{-1}$ dry wt) classified according to the number of moults recovered from each individual

\begin{tabular}{|ccccc|} 
& $\begin{array}{c}0 \\
\text { moults }\end{array}$ & $\begin{array}{c}1 \\
\text { moult }\end{array}$ & $\begin{array}{c}2 \\
\text { moults }\end{array}$ & $\begin{array}{c}3 \\
\text { moults }\end{array}$ \\
\cline { 1 - 3 } & 74.5 & 71.5 & 70.4 & 85.6 \\
& 80.3 & 82.5 & & \\
& 66.0 & 71.9 & & \\
& 76.7 & 73.8 & & \\
& & 97.9 & & \\
\cline { 1 - 3 } Mean zinc & & & & \\
concentration & 74.4 & 80.2 & 70.4 & 85.6 \\
SD & 6.1 & 10.1 & - & - \\
\hline
\end{tabular}

\section{Experiment III: zinc flux through individual tissues}

\section{Concentration of zinc in experimental media}

During the first $20 \mathrm{~d}$, monitoring of the Zn-65 activity in TMN showed maximum losses of $8 \%$, most of which could be attributed to physical adsorption onto perspex boxes and tanks since accumulation of labelled zinc by shrimp was estimated to account for only $1 \%$ of the total losses. The declared concentration of $100 \mu \mathrm{g}$ $\mathrm{Zn} \mathrm{l}^{-1}$ will therefore be used throughout. It was assumed that throughout Days 20 to 49 , total zinc concentrations would not differ significantly from those during the first $20 \mathrm{~d}$.

The maximum concentration of labelled zinc in samples of TMN taken after Day 20 was $1 \mu \mathrm{g} \mathrm{Zn} 1^{-1}$. This amount, lost from shrimp, was considered to represent negligible recycling of labelled zinc.

Distribution of zinc in tissues of Palaemon elegans

Table 3 gives the concentration of zinc and the percentage of the total zinc body burden and dry weight in tissues of Palaemon elegans (pooled from 4 
Table 3. Palaemon elegans. Zinc concentration and percentage body burden (total and soft tissue), and percentage dry weight of pooled tissues of (unexposed) shrimp from Millport. Means (SD); $n=3$ in each case

\begin{tabular}{|c|c|c|c|c|c|}
\hline Tissue & $\begin{array}{c}\text { Zinc conc. } \\
\left(\mu \mathrm{g} \mathrm{g}^{-1} \text { dry wt. }\right)\end{array}$ & $\begin{array}{l}\% \text { of total zinc } \\
\text { body burden }\end{array}$ & $\begin{array}{l}\% \text { of zinc in } \\
\text { soft tissues }\end{array}$ & $\begin{array}{l}\% \text { of total } \\
\text { dry weight }\end{array}$ & $\begin{array}{c}\% \text { of soft tissue } \\
\text { dry weight }\end{array}$ \\
\hline Cuticle & $74.8 \quad(5.4)$ & $48.4(4.0)$ & - & $52.2(4.7)$ & - \\
\hline Muscle & $49.6(2.6)$ & $17.2(1.9)$ & $33.3(3.6)$ & 28.0 & $58.6(3.0)$ \\
\hline Hepatopancreas & $178.4 \quad(31.9)$ & $17.2(1.0)$ & $33.3(2.3)$ & $8.0(1.9)$ & $16.9(4.6)$ \\
\hline Gill & $136.0(9.6)$ & $2.1(0.3)$ & $4.1(1.0)$ & $1.3(0.1)$ & $2.7(0.3)$ \\
\hline Eye & $215.3(40.0)$ & $3.5(0.6)$ & $6.8(1.1)$ & $1.3(0.1)$ & $2.7 \quad(0.3)$ \\
\hline Rest & $101.2(12.9\}$ & $11.6(2.9)$ & $22.5(3.9)$ & $9.2(2.6)$ & $19.1(3.6)$ \\
\hline TISSUE TOTAL & $80.6(4.7)$ & & & & \\
\hline
\end{tabular}

ind.), dissected immediately upon receipt from Millport. The data show that zinc is not evenly distributed between the individual tissues. Although the hepatopancreas, gills and eyes have the highest concentrations and have zinc contents 1.5 and 3 times their proportional body weight, the greatest quantity of zinc is found in the cuticle, with the muscle and hepatopancreas containing equal proportions of the remainder.

The calculated total body zinc concentrations given in Table 3 can be compared with the concentrations of zinc in 12 whole, undissected shrimp sampled and analysed at the same time. The mean concentration for

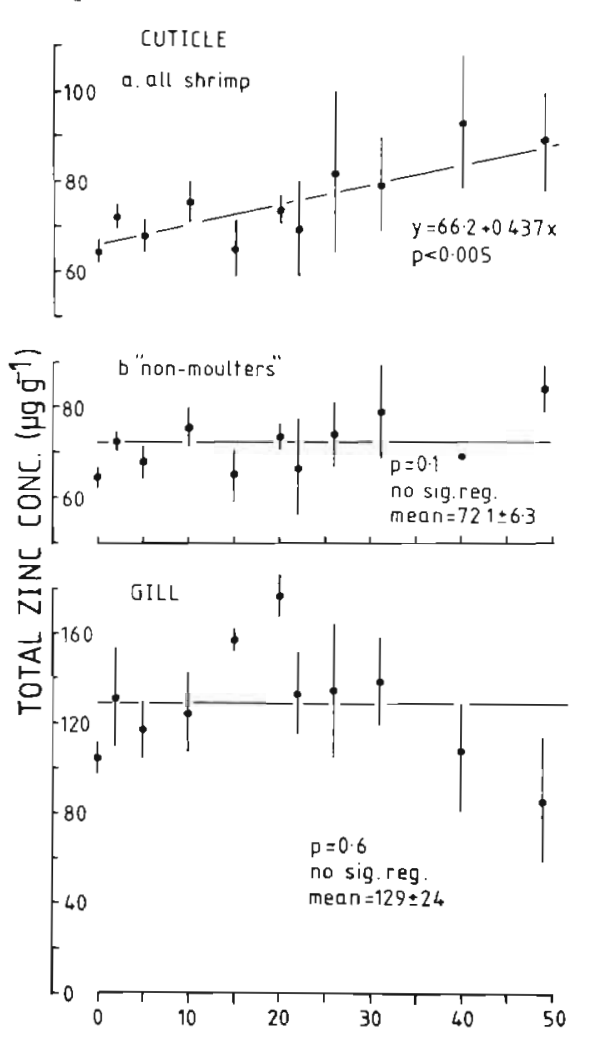

undissected shrimp, $79.5 \mu \mathrm{g} \mathrm{Zn}^{-1}$ (S.D. = 10.1), was not significantly different from that of the tissue totals $80.6 \mu \mathrm{g} \mathrm{Zn} \mathrm{g}^{-1}$ (S.D. $\left.=9.1\right)(\mathrm{p}>0.9)$. It can be concluded that the tissue totals produce a valid estimate of the total body zinc concentration.

Total zinc concentrations: individual tissues

Fig. 5 shows the total zinc concentrations in the dissected tissues of individual shrimp exposed to $100 \mu \mathrm{g} \mathrm{Znl^{-1 }}$ for up to $49 \mathrm{~d}$. Regression analyses

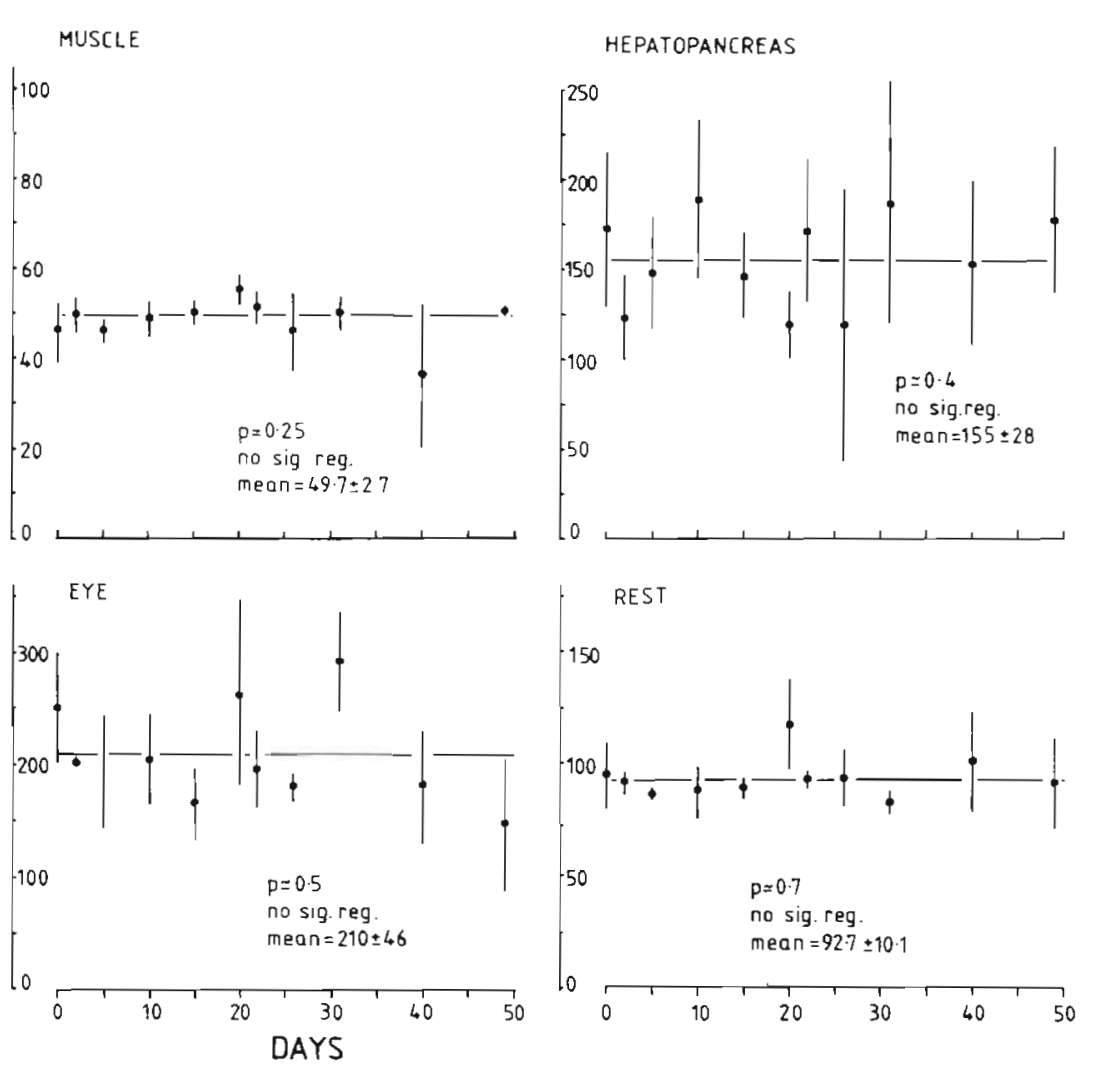

Fig. 5. Palaemon elegans. Concentration of total zinc ( $\mu \mathrm{g} \mathrm{g}^{-1} \mathrm{dry}$ weight, mean $\pm 1 \mathrm{SD} ; \mathrm{n}=4$ ) in individual tissues of shrimp exposed to $100 \mu \mathrm{g} \mathrm{Zn}^{-1}$ for up to $49 \mathrm{~d}_{i}$ Expt. III. Data tested for linear regression against time with the calculated probabilities given. Identification of 'non-moulters' described in text 
revealed that in only 1 tissue, the cuticle, was there a significant increase in the zinc concentration with time $(p<0.005)$, the mean concentration increasing at a rate of approximately $0.44 \mu \mathrm{Zn} \mathrm{g}^{-1} \mathrm{~d}^{-1}$ (Line a). In the other tissues there was some variation in the measured zinc concentration throughout the experiment but the overall mean concentrations (based on all samples) are close to those given in Table 3 .

Total zinc concentrations: tissue totals

Fig. 6 (Line a) shows calculated whole body zinc concentrations of all shrimp based on tissue totals, throughout the experiment. Analysis of variance
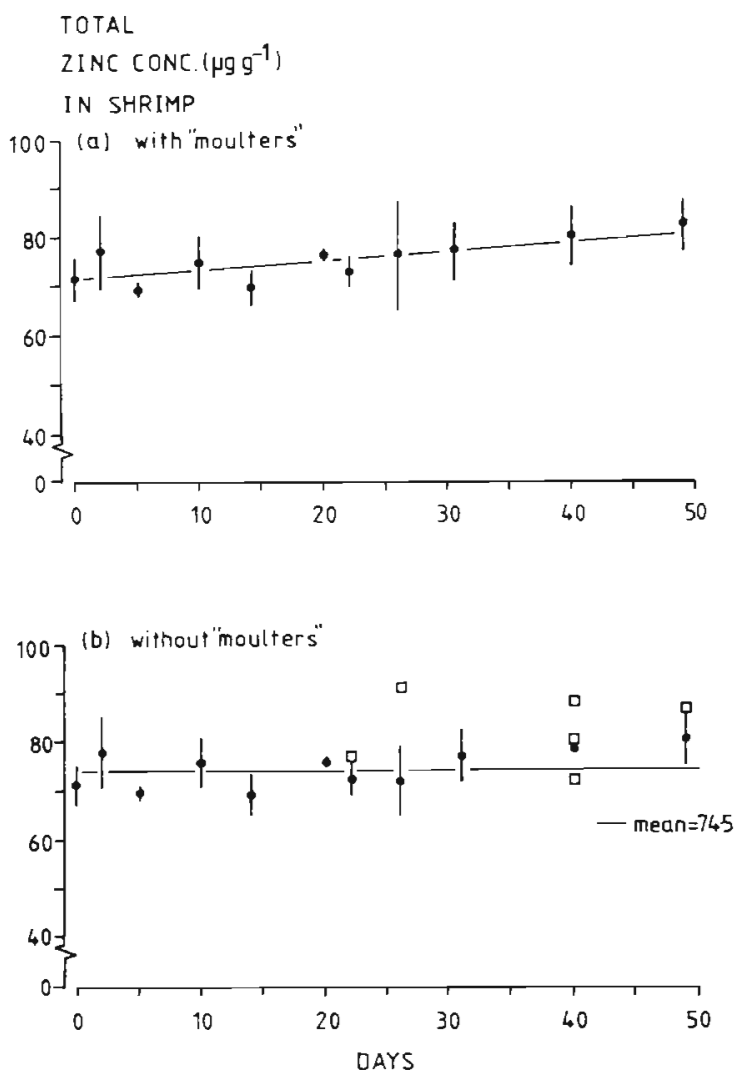

Fig. 6. Palaemon elegans. Total zinc concentration $\left(\mu \mathrm{g} \mathrm{g}^{-1}\right.$ dry weight, mean $\pm 1 \mathrm{SD}_{i} \mathrm{n}=4$ ) in whole shrimp (based on tissue totals) exposed to $100 \mu \mathrm{g} \mathrm{Zn} 1^{-1}$ for up to $49 \mathrm{~d}$; Expt. III (a) with 'moulters'; (b) without 'moulters' but with data for 'moulters' plotted (D). Identification of moulters described later in text

revealed that although the mean zinc concentrations at each sampling occasion did not differ significantly ( $p \simeq 0.1$ ), there is a significant relation between zinc concentration and time of exposure $(p \simeq 0.025)$. The slope of this equation, the apparent rate of net zinc accumulation, is $0.186 \mu \mathrm{g} \mathrm{Zn} \mathrm{g} \mathrm{g}^{-1} \mathrm{~d}^{-1}$. As the cuticle accounts for about $45 \%$ of the total zinc burden of the shrimp, the accumulation of zinc by the cuticle alone produces an increase of $0.197 \mu \mathrm{Zn} \mathrm{g}^{-1} \mathrm{~d}^{-1}$ in the whole individuals, and accounts adequately for the observed increase of $0.186 \mu \mathrm{gn} \mathrm{g}^{-1} \mathrm{~d}^{-1}$ in the whole shrimp.

Accumulation and loss of labelled zinc: individual tissues

Fig. 7 shows the amount of labelled zinc as a percentage of the total zinc concentration in dissected tissues of shrimp sampled throughout the experiment. Fig. 8 illustrates the data totalled for whole shrimp.

During the experiment 8 moults were recovered, 6 during the first $20 \mathrm{~d}$ when labelled zinc was present. Experiments I and II documented that uptake and loss of labelled zinc are affected by moulting, causing an increase in uptake of labelled zinc. It is therefore important to identify those shrimp which had moulted during the experiment. Examining amounts of labelled zinc as a percentage of the total zinc content of individual tissues, in particular the cuticle, showed that 6 shrimp had markedly greater percentages of labelled zinc than others sampled at the same time. These shrimp may therefore be recognised as having moulted and are marked separately on Fig. 7 and 8. These data have been excluded from calculation of uptake and loss of labelled zinc, so reducing the otherwise consequent variability of the data. Examination of the percentage of labelled zinc in individual tissues is not, however, a totally satisfactory technique, as it proved impossible to distinguish the final 2 shrimp corresponding to the moults recorded on Days 25 and 27. It would be expected on the basis of the results of Experiment II that these shrimp would have lower concentrations of labelled zinc in individual tissues (and consequently in tissue totals) than other individuals which had not moulted during the non-labelled phase of the experiment.

An apparent conclusion on the basis of data from all shrimp was that the total zinc concentration in shrimp increased throughout the experiment as a result of accumulation into the cuticle. If, however, the data for the 6 shrimp now identified as having moulted are excluded, the apparent increases in zinc concentrations in the cuticle and the whole shrimp (Fig. 5, cuticle $a$; Fig. 6a) become insignificant $(p \simeq 0.1$ and $p \simeq 0.2$, respectively). The revised data are shown in Fig. 5, cuticle b and Fig. 6b. The new conclusion from this experiment is that zinc body levels of Palaemon elegans are regulated in line with the conclusions drawn in White and Rainbow (1984). It may moreover be inferred that moulting in a high external zinc concentration $\left(100 \mu \mathrm{g} \mathrm{Zn} 1^{-1}\right)$ causes some (possibly temporary) increase in the total zinc concentration in the cuticle and hence in shrimp as a whole. 


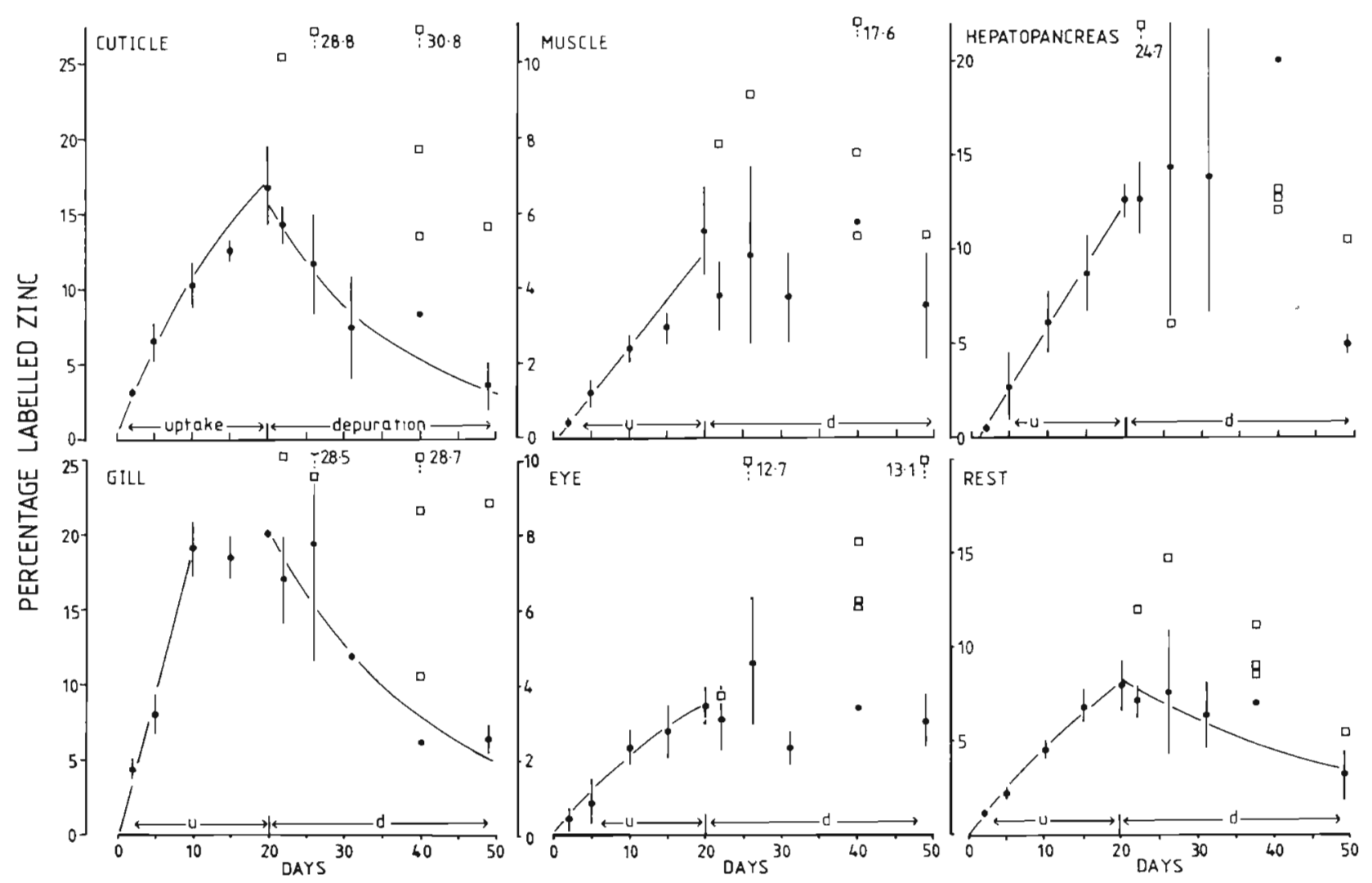

Fig. 7. Palaemon elegans. Accumulation and loss of labelled zinc (as a percentage of total body zinc) in individual tissues of shrimp exposed to $100 \mu \mathrm{g} \mathrm{l}^{-1}$ of labelled zinc to Day 20 (uptake $=\mathrm{u}$ ) and then to $100 \mu \mathrm{g} \mathrm{l}^{-1}$ of unlabelled zinc up to Day 49 (depuration $=\mathrm{d}$ : means $\pm 1 \mathrm{SD}$ ); Expt. III. Means do not include data for shrimp identified as having moulted during the first $20 \mathrm{~d}$ of experiment (see text). Data for these individuals shown separately ( $\square$ ). Fitted accumulation and loss curves significant at the $p<0.05$ probability level

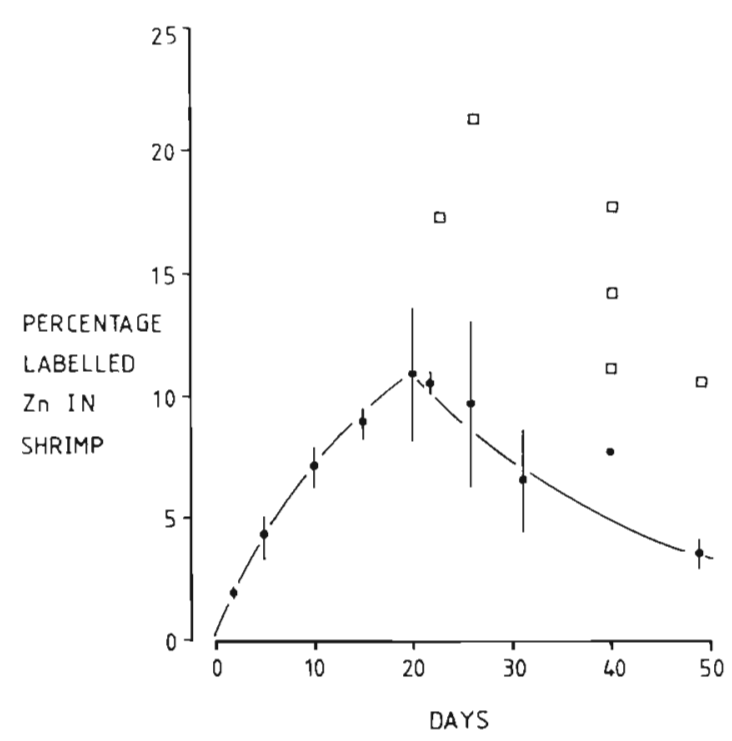

Fig. 8. Palaemon elegans. Accumulation and loss of labelled zinc (as a percentage of total body zinc) in whole shrimp (based on tissue totals) exposed to $100 \mu \mathrm{g} \mathrm{l}^{-1}$ of labelled zinc up to Day 20 and than to $100 \mu \mathrm{g}^{-1}$ of unlabelled zinc up to Day 49 (means $\pm 1 \mathrm{SD}$ ); Expt. III. Other details as for Fig. 7
As the concentration of total zinc did not change significantly in individual tissues nor in the tissue totals of non-moulted shrimp, uptake and loss of labelled zinc can be studied using the compartmental steady-state kinetics described in White and Rainbow (1984). The asymptotes (Fig. 7) fitted to the cuticle, eye and rest data are probably not the maximum amounts that these tissues would take up, as had exposure to labelled zinc continued indefinitely the more refractory (slow pool) zinc in these tissues would all eventually have exchanged with labelled zinc. Although the uptake data for the gill cannot be fitted to an asymptotic curve over the experimental period, Fig. 7 shows that the percentage of labelled zinc increases rapidly and then levels off, after Day 10, to approximately $18 \%$.

Although made up from both linear and asymptotic components the data for the tissue totals can still be adequately fitted to an asymptotic curve (Fig. 8), probably largely as a result of the observed asymptotes in the cuticle and rest which account for approximately $60 \%$ of the total body zinc content.

As total zinc concentration in individual tissues of 
Table 4. Palaemon elegans. Uptake and loss of labelled zinc, and flux of total zinc through individual tissues of shrimp exposed to $100 \mu \mathrm{g} \mathrm{Zn} \mathrm{l}^{-1}$ at $10^{\circ} \mathrm{C}$ : NSL: no significant loss

\begin{tabular}{|c|c|c|c|c|}
\hline \multirow[b]{2}{*}{ Tissue } & \multirow[b]{2}{*}{$\begin{array}{c}\text { Uptake of } \\
\text { labelled zinc }\end{array}$} & \multirow[b]{2}{*}{$\begin{array}{l}\text { Loss of } \\
\text { labelled zinc }\end{array}$} & \multicolumn{2}{|c|}{ Flux of total zinc } \\
\hline & & & $\begin{array}{c}\% \text { of } \mathrm{Zn} \\
\text { in tissue } \mathrm{d}^{-1}\end{array}$ & $\begin{array}{l}\mu g g^{-1} \\
\text { of tissue } d^{-1}\end{array}$ \\
\hline Cuticle & Asymptotes to $26.4 \%$ & $\mathrm{~T}_{\mathrm{b} / 2}=15.6 \mathrm{~d}$ & $1.38 \%$ & 1.02 \\
\hline Muscle & Linear uptake & NSL & $0.26 \%$ & 0.13 \\
\hline Hepatopancreas & Linear uptake & NSL & $0.45 \%$ & 2.41 \\
\hline Gill & Linear uptake & $\mathrm{T}_{\mathrm{b} / 2}=15.0 \mathrm{~d}$ & $1.87 \%$ & 1.01 \\
\hline Eye & Asymptotes to $6.6 \%$ & NSL & $0.25 \%$ & 0.53 \\
\hline Rest & Asymptotes to $20.1 \%$ & $\mathrm{~T}_{\mathrm{b}^{1 / 2}}=22.6 \mathrm{~d}$ & $0.53 \%$ & 0.49 \\
\hline Tissue total & Asymptotes to $16 \%$ & $\mathrm{~T}_{b / 2}=18.4 \mathrm{~d}$ & $0.95 \%$ & 0.71 \\
\hline
\end{tabular}

non-moulted shrimp is constant throughout the experiment, the initial rate of uptake of labelled zinc equals the total zinc flux rate. Table 4 lists this derived rate of zinc flux as both the percentage of total zinc and the amount of zinc per $g$ of dry tissue per day, the rates being calculated from either the calculated linear regression or from the tangents to the fitted asymptotic curves. There are marked differences in zinc flux rates through individual tissues, zinc flux through the hepatopancreas being approximately 20 times that through the muscle per unit weight.

Only 3 tissues - the cuticle, gill and rest - showed significant losses of labelled zinc with time during the depuration phase. The rates of labelled zinc uptake and loss in the cuticle and rest are not significantly different $(p \simeq 0.5$ and $p=0.2$, respectively). Labelled zinc loss from the gill, approximately $0.92 \%$ of the total zinc content per day, was less than half that of uptake $(1.87 \%)$. While this may indicate some incorporation of labelled zinc into more refractory zinc pools within the gills, net loss of labelled zinc during the depuration period may have been slowed by transfer of labelled zinc into the gill from other tissues. It is possible therefore that the gill is involved in loss of labelled zinc.

Muscle, hepatopancreas and eyes showed no significant decrease in the percentage of labelled zinc during the depuration phase. Labelled zinc loss from whole shrimp (tissue totals; Fig. 8) can be fitted to an exponential curve with a calculated biological half-life $\left(t_{b^{1 / 2}}\right)$ of $18.4 \mathrm{~d}$. The rate of labelled zinc uptake $0.71 \mu \mathrm{g}$ $\mathrm{Zn}^{-1} \mathrm{~d}^{-1}$ is significantly greater $(\mathrm{p}<0.001$ ), than the rate of loss, $0.31 \mu \mathrm{g} \mathrm{g}^{-1} \mathrm{~d}^{-1}$

Fig. 9 shows the amount of labelled zinc in the cuticle as a proportion of the tissue totals in shrimp. The plotted means exclude data from shrimp identified as having moulted, these being shown separately. The

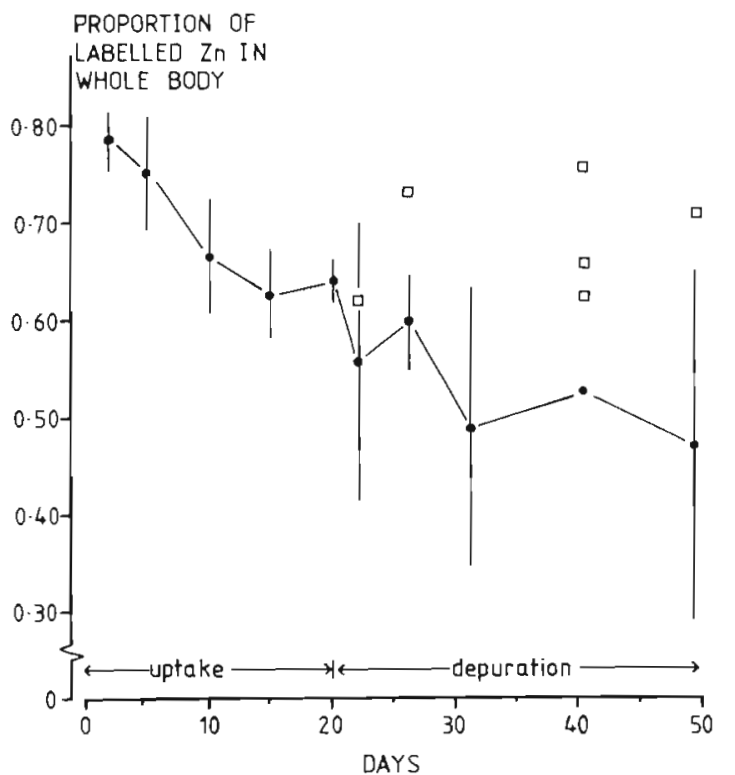

Fig. 9. Palaemon elegans. Proportion of labelled zinc in cuticle of shrimp exposed to $100 \mu \mathrm{g} \mathrm{l}^{-1}$ of labelled zinc up to Day 20 and then to $100 \mu \mathrm{g}^{-1}$ of unlabelled zinc up to Day 49. Data expressed as proportion of total body burden (tissue totals: means $\pm 1 \mathrm{SD}$ ). Expt. III. Other details as for Fig. 7

cuticle initially has a proportion of labelled zinc considerably greater than its proportional body burden of total zinc (48.4\%). This high initial proportion is probably due to rapid adsorption of labelled zinc onto the cuticle, displacing non-labelled zinc, the proportion decreasing as other tissues more slowly take up labelled zinc. During the depuration phase the decrease in the labelled zinc burden in the cuticle continues, the proportion approaching the stable zinc burden by Day 49. This continued decrease is to be expected as the loss of labelled zinc from the cuticle is faster than from the shrimp as a whole (Fig. 7, 8; Table 3). 


\section{DISCUSSION}

\section{Individual variation and effects of moulting}

A feature of the zinc flux experiments reported by White and Rainbow (1984) was the considerable variation in flux between individual shrimp, prompting this more detailed study.

The occurrence of a large number of moults during the accumulation phase of Experiment II makes it difficult to examine possible causes of the 2 to 3 fold variation in the rates of zinc flux between individual shrimp (White and Rainbow, 1984). Analysis of the data for the loss of labelled zinc, however, showed no correlation $(r=0.07, p \simeq 0.5$ ) between the calculated zinc half life and the size (dry weight) of the shrimp nor was there any significant difference in the mean zinc half lives in males and females $(p \simeq 0.4)$. Thus the observed variation cannot be attributed to either size or sex of the shrimp and consequently any other factors that may vary with these 2 characteristics, such as surface area, metabolic rate, or differential activity between sexes. It can be speculated that the observed variation in zinc flux rates is a consequence of the large gene pool from which populations of Palaemon elegans arise. Planktonic post-larval stages of the shrimp settling out at a particular site may be drawn from a number of widespread parental populations causing a mixing of the gene pool and maintaining a genotypically heterogeneous population at a given site with resultant physiological variability. There would be little selection pressure to reduce this variability as total body zinc concentrations in $P$. elegans are well regulated even at relatively elevated external zinc levels, apparently independently of zinc flux rates, so long as zinc levels remain below a threshold value (White and Rainbow, 1982, 1984). Selection pressures would therefore only come into play under conditions of extreme zinc contamination where the zinc regulatory abilities of the shrimp break down. In this case any shrimp with a slow rate of net zinc uptake, reducing the rate at which the maximum tolerable level of zinc is reached (White and Rainbow, 1982), would have a selective advantage.

Moulting has a considerable effect on the rate of zinc flux in individual shrimp. Zinc flux clearly increased on moulting but it is difficult to determine precisely the size of this effect as it is not discrete, increased labelled zinc uptake (and hence total zinc flux) generally continuing for some time after moulting has occurred. This may result in exceptionally rapid labelled zinc uptake by shrimp that moult shortly before the start of an experiment as concluded for cadmium uptake in Crangon crangon by Dethlefsen (1978), and as may be the case for Individuals 7 and 11 in Experiment II (Fig. 3).
There is little evidence, however, to suggest that the variation between individuals discussed above is solely due to differences in flux rates throughout the moult cycle. For a particular point in the moult cycle, such as immediately before moulting, an examination of the data for Experiments I and II and in White and Rainbow (1984) still shows considerable variation in zinc uptake rate.

In Experiment II Individuals 1, 3, 9 and 12 (Fig. 3) show that after moulting and while still exposed to labelled zinc, the net labelled zinc content rises (at an enhanced rate) but subsequently falls to some extent. It is not clear what these decreases represent as it would be expected that the labelled zinc content would continue to rise or remain constant during exposure to labelled zinc. It is possible, however, that there is a rapid influx of labelled zinc during and after moulting causing a temporary net increase in the total zinc concentration of the shrimp, there being some delay before this excess is lost and regulation restored. This temporary increase in zinc concentration may be due to an increase in the number of zinc adsorption sites on the cuticle. As the cuticle hardens a number of these sites may be lost with some loss of labelled zinc.

Amounts of labelled zinc lost by Palaemon elegans on moulting depended upon the time between the start of the exposure and moulting. For shrimp exposed to labelled zinc for $10 \mathrm{~d}$, the loss was approximately 15 to $20 \%$ of the total accumulated on Day 10 (Experiment II), whereas for shrimp that moulted shortly after exposure started (Experiment I) losses were considerably greater, approximately $45 \%$ of the estimated total. The differences are probably due to the greater proportion of labelled zinc associated with the cuticle early in the experiment as a result of the rapid exchange between unlabelled and labelled zinc on the cuticular surface, as seen in Experiment III (Fig. 9).

It was not possible to determine amounts of labelled zinc lost with subsequent moults as losses were smaller than variations about the calculated regression lines (Experiment II). It is probable therefore that only the initial moult after exposure to labelled zinc is important as a route of labelled zinc loss. There appears to be some variation between species in amount of labelled zinc lost on moulting; Renfro et al. (1975) reported that in the shrimp Lysmata seticaudata labelled zinc loss on moulting is approximately $45 \%$ of the body burden though it is not clear if this proportion loss is maintained through successive moults. In Euphausia pacifica labelled zinc loss on moulting is considerably less, approximately $1 \%$ of the total body burden, but in this case the percentage loss is constant with successive moults (Fowler et al., 1971). The comparatively lower proportion of labelled zinc lost in E. pacifica may be due to the method of 'labelling', via food (Fowler et 
al., 1975), rather than via seawater as in $L$. seticaudata (Renfro et al., 1975), and in this study in Palaemon elegans.

Rapid labelled-zinc uptake by moults shed into labelled media largely invalidates their direct use to quantify the role of moulting in the zinc budget of Palaemon elegans. Similar metal uptake by cast moults has also been found for cadmium and also occurs with copper (unpubl. own obs.). These results have some relevance to studies on the role of marine organisms in the transport of trace elements and radionuclides in the sea. Such studies have considered the concentration of metals in the cuticles of various crustacea (Bertine and Goldberg, 1972; Higgo et al., 1977) or have analysed moults at varying times after being shed (Small et al., 1973; Fowler, 1977). Reabsorption of heavy metals from the cuticle and the adsorption of metals onto the shed moult will tend to over-and underestimate, respectively, the importance of moults in the cycling of trace elements in the sea. While these 2 effects will, to some extent, cancel each other out, knowledge of their relative importance for particular species will improve the accuracy of estimates determining the part played by biological processes in the cycling of trace elements in the sea.

\section{Distribution of zinc in crustacean tissues}

Table 5 compares the concentrations of zinc in individual tissues of selected crustaceans and shows that zinc is not homogeneously distributed. While there is some variation in zinc concentrations between species there are a number of generalised points. The concentration of zinc in the cuticle varies inversely with the degree of calcification. However, it is possible that part of this apparent trend may be due to the high surface area per unit weight in the cuticle of relatively small euphausids increasing the importance of surface adsorbed zinc. Concentration of zinc in the abdominal muscle is generally lower than that of the whole individual (see also Bryan, 1968). While Experiment III suggests that the gill may be a major site of zinc uptake in Palaemon elegans (see also Bryan, 1968), the zinc concentrations are not exceptional, being roughly equal to, or less than, the concentration in the hepatopancreas. Although there are limited data available, the zinc concentrations in the eye are surprisingly high. This may be due to high concentrations of zinc metalloenzymes such as alcohol dehydrogenase, known to be associated with the visual process (Wald and Hubbard, 1960). High concentrations of zinc (> 10,000 $\mu \mathrm{g} \mathrm{Zn} \mathrm{g}^{-1}$ ) have also been found in the choroid of mammalian eyes, specifically in the light reflective tapetum (Vallee, 1959) and it is possible that similar localisation of zinc occurs in the analogous tapetum of crustacean superposition eyes.

\section{The effect of moulting on total body zinc concentra- tions}

In Experiment III 6 shrimp, identified as having moulted on the basis of high percentages of labelled zinc, additionally had raised total zinc concentrations. Mean zinc concentration of these moulted shrimp was $9 \mu \mathrm{g} \mathrm{Zn} \mathrm{g}^{-1}$ higher than in shrimp which did not moult. Such increases in total zinc concentrations of moulted shrimp were not found in Experiments I and II reported here, nor in those reported in White and Rainbow (1984), probably as a result of the lower dissolved zinc concentrations used in those experiments. These lower zinc concentrations would tend to reduce the amount of zinc accurnulated on moulting, making any increases too small to detect above the variability in zinc concentrations between individual shrimp.

As there was no significant change in the zinc concentrations in other tissues of shrimp identified as having moulted it appears that the additionally accumulated zinc is confined to the cuticle. It is poss-

Table 5. Concentrations of zinc in tissues of selected crustaceans ( $\mu \mathrm{g} \mathrm{g}^{-1} \mathrm{dry}$ weight). Not all tissues analysed are listed

\begin{tabular}{|c|c|c|c|c|c|c|c|}
\hline Crustacean & $\begin{array}{c}\text { Cuticle } \\
\text { 'exoskeleton' } \\
\text { shell' }\end{array}$ & $\begin{array}{l}\text { Abdominal } \\
\text { muscle } \\
\text { ('tail') }\end{array}$ & $\begin{array}{c}\text { Hepatopancreas } \\
\text { ('midgut gland/ } \\
\text { liver") }\end{array}$ & Gill & Eye & $\begin{array}{c}\text { Whole } \\
\text { individual } \\
\text { (tissue totals) }\end{array}$ & Source \\
\hline Euphausids & 120 & - & - & - & 125 & - & Fowler et al. (1970) \\
\hline Shrimps/prawns & 92 & $66^{\circ}$ & 37 & - & 139 & - & Fowler et al. (1970) \\
\hline Palaemon elegans & 75 & 50 & 178 & 136 & 215 & 81 & This study \\
\hline Pandalus montagui & - & 45 & 120 & - & - & 70 & Ray et al. (1980) \\
\hline Cancer imoratus" & $10-20$ & $220-250$ & $70-150$ & $85-120$ & - & - & Martin (1975) \\
\hline $\begin{array}{l}\text { Homarus gammarus } \\
\text { (vulgaris) }\end{array}$ & 7 & 59 & 83 & 101 & - & 66 & Bryan (1976) \\
\hline
\end{tabular}


ible therefore that this additional zinc may be lost when the next exuvia is shed, and so repeated moulting in elevated concentrations of zinc would not necessarily lead to a series of discrete increases in total body zinc concentrations. There is some supporting evidence in Experiment II, where individual shrimp moulted up to 3 times, but showed no significant increase in total zinc concentration (Table 2)

\section{Zinc flux through individual tissues}

White and Rainbow (1984) described uptake and loss of labelled zinc by Palaemon elegans in terms of accumulation into fast and slow pools, producing an apparent asymptote in the pattern of uptake as the last pool of zinc filled with labelled zinc. The data in this study show that the pattern of uptake differs between different tissues. In the hepatopancreas, gill and muscle labelled zinc uptake is apparently linear with time suggesting that all zinc in these tissues exchanges at the same rate. In the cuticle, rest and eyes the amount of labelled zinc appears to asymptote towards different percentages, all significantly less than $100 \%$.

As discussed by White and Rainbow (1984) the linear and asymptotic patterns of labelled zinc uptake are only approximate. In the apparently linearly accumulating tissues the amount of labelled zinc will eventually asymptote to $100 \%$, there presumably having insufficient accumulation to cause any significant curvature towards this asymptote. The apparent asymptotes determined for eyes, rest, and cuticle are probably due to the rapid exchange between labelled and non-labelled zinc of only a fraction of the total zinc in each tissue. Individual tissues also show considerable variation in the rate of labelled zinc uptake. The hepatopancreas and muscle show approximately linear accumulation of labelled zinc over the initial $20 \mathrm{~d}$ but zinc flux rates are 2.41 and $0.13 \mathrm{~g} \mathrm{Zn} \mathrm{g}^{-1} \mathrm{~d}^{-1}$, respectively. The apparent asymptotes also show considerable variation, $26.4 \%$ and $6.6 \%$ of the total zinc content of the cuticle and eye, respectively. It is clear therefore that the terms 'fast' and 'slow', when applied to pools of zinc within tissues, are relative, being considerably variable in nature between tissues.

Data for tissue totals, the sum of both apparently linear and asymptotic components with a variety of uptake rates, can be adequately described by an asymptotic curve approaching $16.0 \%$ of the total body zinc content under the particular experimental conditions employed (see White and Rainbow, 1984).

The pattern of labelled zinc loss from individual tissues is considerably more complex than that of uptake. Although tissue totals show a net loss of labelled zinc of $4.1 \% \mathrm{~d}^{-1}$ only gill, cuticle, and rest showed significant net losses. As there is no net accumulation of total zinc in any of the tissues (of non-moulted shrimp) this indicates that there is transfer of labelled zinc between tissues, such that not all of the losses observed in the gill, rest or cuticle are necessarily lost to the exterior. The difference in the rates of uptake and loss of labelled zinc in whole shrimp may be explained by its net transfer to the slow pools of individual tissues (White and Rainbow, 1984).

The amount of labelled zinc associated with the cuticle is of particular interest with regard to zinc flux on moulting. In Experiment II the percentage of the total labelled zinc body burden lost on moulting was 15 to $20 \%$ of the total accumulated. The amount of labelled zinc associated with the unshed cuticle, however, was found in this experiment to be between 47 and $78 \%$ of the body burden, depending upon the duration of exposure (Fig. 7). This indicates that not all of the labelled zinc in the cuticle is lost with the moult and that zinc is reabsorbed as is the case for calcium (Travis, 1955). It is not clear if labelled zinc is then redeposited into the new cuticle.

Acknowledgements. S. L. W. was in receipt of an S. R. C. studentship during this work. It is a pleasure to thank Mr. A. G. Scott for his advice on analytical matters.

\section{LITERATURE CITED}

Bertine, K. K., Goldberg, E. E. (1972). Trace elements in clams, mussels and shrimp. Limnol. Oceanogr. 17: $877-884$

Bryan, G. W. (1964). Zinc regulation in the lobster Homarus vulgaris 1. Tissue zinc and copper concentrations. J. mar. biol. Ass. U.K. 44: 549-563

Bryan, G. W. (1968). Concentrations of zinc and copper in the tissues of decapod crustaceans, J. mar. biol. Ass. U.K. 48: 303-321

Bryan, G. W. (1976). Heavy metal contamination in the sea. In: Johnston, R. (ed.) Marine pollution. Academic Press, London, p. 185-302

Dethlefsen, V. (1978). Uptake, retention and loss of cadmium by brown shrimp (Crangon crangon). Meeresforschung 26: $137-152$

Fowler, S. W. (1977). Trace elements in zooplankton particulate products. Nature, Lond. 269: 51-53

Fowler, S. W., Small, L. F., Dean, J. M. (1970). Distribution of ingested zinc-65 in the tissues of some marine crustaceans. J. Fish. Res. Bd Can. 27: 1051-1058

Fowler, S. W., Small, L. F., Dean, J. M. (1971). Experimental studies on the elimination of zinc-65, cesium-137 and cerium-144 by euphausids. Mar. Biol. 8: 224-231

Fowler, S. W., La Rosa, J., Heyraud, M., Renfro, W. C. (1975). Effect of different labelling techniques on radionuclide excretion from marine organisms. Mar. Biol. 30: 297-304

Heyraud, M., Fowler, S. W. (1973). Comparative studies on the bioretention of radionuclides under laboratory and field conditions. Thalassia jugosl. 9: 127-137

Higgo, J. J. W., Cherry, R. D., Heyraud, M., Fowler, S. W (1977). Rapid removal of plutonium from the oceanic sur- 
face layer by zooplankton faecal pellets. Nature, Lond. 266: 623-624

Martin, J.-L. M. (1975). Le cuivre et le zinc chez Cancer irroratus (Crustace: Decapode): metabolism compare au cours du cycle d'intermue. Comp. Biochem. Physiol. 51 A: $777-784$

Ray, S., McLeese, D. W., Waiwood, B. A., Pezzack, D. (1980). The disposition of cadmium and zinc in Pandalus montagui. Archs environ. Contam. Toxicol. 9: 675-681

Renfro, W. C., Fowler, S. W., Heyraud, M., La Rosa, J. (1975). Relative importance of food and water in long term zinc65 accumulation by marine biota. J. Fish. Res. Bd Can. 32: 1339-1345

Small, L. F., Fowler, S. W. (1973). Tumover and vertical transport of zinc by the euphausid Meganactiphanes norvegica in the Ligurian Sea. Mar. Biol. 18: 284-290

Small, L. F., Fowler, S. W., Keckes, S. (1973). Flux of zinc through a macroplanktonic crustacean. In: Anon (ed.) Radioactive contamination of the marine environment.
International Atomic Energy Agency, Vienna, p. 437-452 Travis, D. F. (1955). The moulting cycle of the spiny lobster Palinurus argus Latreille. II. Pre-ecydysial histological and histochemical changes in the hepatopancreas and integumented tissues. Biol. Bull. mar. biol. Lab., Woods Hole 108: 88-112

Vallee, B. L. (1959). Biochemistry, physiology and pathology of zinc. Physiol. Rev. 59: 443-490

Wald, G., Hubbard, R. (1960). Enzymic aspects of the visual processes. In: Boyer, P. D., Lardy, H., Myrbuck, K. (ed.) The enzymes, Vol. 3. Prosthetic groups and cofactors (Part B), 2nd ed. Academic Press, New York, p. 369-386

White, S. L., Rainbow, P. S. (1982). Regulation and accumulation of copper, zinc and cadmium by the shrimp Palaemon elegans. Mar. Ecol. Prog. Ser. 8: 95-101

White, S. L., Rainbow, P. S. (1984). The regulation of zinc concentration by Palaemon elegans (Crustacea: Decapoda): zinc flux and the effects of temperature, zinc concentration and moulting. Mar. Ecol. Prog. Ser. 16: 135-147 